\title{
A Structure of Conflicts in the Poetry of Dennis Brutus
}

\author{
Kontein Trinya ${ }^{1, *}$ \\ ${ }^{1}$ Department of English Studies, Faculty of Humanities, University of Education, Port Harcourt, Nigeria \\ *Correspondence: Department of English Studies, Faculty of Humanities, University of Education, Port Harcourt, \\ Nigeria. Tel: 234-803-338-8489. E-mail: kontein@hotmail.com
}

Received: December 10, 2014 Accepted: January 6, 2015 Online Published: January 21, 2015

doi:10.5430/wjel.v5n1p1 URL: http://dx.doi.org/10.5430/wjel.v5n1p1

\begin{abstract}
Much has been commended about the poetry of Dennis Brutus the anti-Apartheid South African. A unique feature of the poet, which this paper investigates, is his binary vision of the conflicts in his pre-independence society; conflicts involving two 'parts' in opposition, reflective of the perennial conflicts between the forces of Apartheid on one hand, and the oppressed on the other. Brutus's vision finds eloquent expression in the binary structure of his poetry, a structure executed especially in his images that often involve two opposing parts, or comprising two parts related at the same time as they are paradoxically opposed. It is the poet's stylistic projection of his context, as well as the commitment of his art to social cause.
\end{abstract}

Keywords: South African poetry; Dennis Brutus; structure; images; binaries; apartheid literature; protest literature

\section{Beauty and Duty in the Poetry of Brutus}

Dennis Brutus the prominent anti-apartheid South African poet is respected the world over as "one of the most distinguished contemporary South African poets" (Wisner-Broyles, 1999), as "one of Africa's most celebrated poets" (Bond, 2009), as a man who "devoted his life and his art to opposing apartheid in South Africa" (Sanchez, 2003).

A unique feature of Dennis Brutus's poetry, which this paper investigates, is his binary vision of the conflicts in his country; conflicts involving two 'parts' in opposition, reflective of the perennial conflicts between the forces of Apartheid on one side, and the oppressed freedom fighters on the other. This vision finds eloquent expression both in the structure of his poetry as well as in the images that often comprise two opposing 'parts,' or images composed of two parts related at the same time as they are opposite.

Brutus does not shy away from social responsibility in his poetry. He merely subsumes duty under beauty. In an interview with Cosmo Pieterse (1978, pp. 59-60) in African Writers Talking, one of the views he expressed was that both social relevance and artistic skill could combine usefully to make good poetry. Brutus stressed his necessary combination of beauty and duty in that interview when he admitted, for instance, to the presence, in his poetry, of counterpoints (which this paper occasionally describes in terms of binaries, or units of paired opposites). Those counterpoints, Brutus stated in that interview, generated tension in the poetry, a technically contrived poetic tension, which he said was "partly a deliberate desire to catch [social] tension" and partly because "tension is of the essence of good poetry" (p. 54); in other words, a concurrence of artistic beauty and social relevance.

\section{The Social Imperatives of South African Literature}

Another issue highlighted by the interview, as Pieterse put it, was Brutus's "very many meanings locked into single words, into single lines, and certainly innumerable meanings in a whole poem," and the consequent complexity of such poems. The poet's reply to that was to state that he had turned "to a very much simpler, very prosaic use of language" (p. 56).

Like Lewis Nkosi (1981) in Tasks and Masks, Claude Wauthier (1978) in The Literature and Thought of Modern Africa saw apartheid South African literature as a mirror of South Africa, especially when he cited Nadine Gordimer's comments in Rand Daily Mail, that 
the works of black writers were for the Europeans the best, if not the only way of knowing 'what black South Africans, who have no voice in the parliament nor any say in the ordering of their life, think and feel.' (p. 334)

In "Sharpeville and its Aftermath...," Prof. M.V. Mzamane (1989), who passed on recently on February 16, 2014, pursued the same line of argument that Black South African literature was "closely tied to political developments," which it mirrored (p. 31). Archbishop Desmond Tutu (2014) shared the same predominantly social perspective when he stated,

We in South Africa needed the support of the international community in our efforts to end the vicious system of racial oppression called apartheid. We had to have eloquent advocates to tell the world our story and persuade it to come to our assistance.... We had none more articulate and with all the credibility and integrity so indispensable than Dennis Brutus to plead our cause.

\section{Visions of Conflict on Paradigms of Metaphor}

Poetry provided the prominent platform from which Dennis Brutus staged his agitations against oppression. The poet's vision of South Africa was that of a conflict society, comprising a dissimilar but complemental pair. Accordingly, one often finds in the poems several levels of dissimilar but related dualities, suggesting several levels of conflict that point ultimately to the several levels of social oppositions that the poet describes; oppositions between Apartheid on the one hand, and its several oppressed victims on the other. Thus, the conflict which the poet sees in his society finds expression in the oppositions he creates in his poetry, for example, oppositions in his images, in his lyricism, in his conception of his role as an artist, etc.

This technique of creating dual dissimilarities involving paired 'units' of images or moods or musical forms or sounds, etc., comprising two opposing (though related) parts, runs virtually through his poetry and becomes, as it were, its unifying structure. The dissimilarity of their parts notwithstanding, there is usually a 'whole' in the picture that Brutus's images present, a 'whole' that derives from the relationship of the paired 'parts'; 'parts' which relate to each other usually in the nature of their opposition one to the other.

Sometimes, much more than an opposition, one notices a counterposition, where one part of the relating pair seems positioned to balance the other part, thus creating the tension which has been noted as characteristic of this technique of Brutus. In this way, the poet's vision often assumes a universal scope that encompasses not only the victims in his society but "all suffering people" (Wisner-Broyles, 1999).

In the poem, "Land that I love, now must I ask" (1978, p. 14), for example, we notice an instance of that characteristic creation of paired opposites in the image of the "permanent heart / glimmering and tender in the luminous dark" (my emphasis). The image is "unified' by its reference to a single "permanent heart"; yet there are two notionally opposite parts to that image: "luminous" and "dark."

\section{Brutus's Binary Images}

This structure of simultaneous dissimilarities does not always consist of a single image comprising two different (and often opposing) parts, as in the oxymoron of the "luminous dark." Sometimes it comprises two different images related essentially by their contrasting nature. In Brutus's prison poems in "Letters to Martha," for instance, especially in Letter No. 17, we find the images of the sailing clouds and free flying birds bound (at the same time as they are in opposition) to the image of the incarcerated observer. Both juxtaposed parts of that 'unit' are related further by their reference to and unique amplification of the plight of the incarcerated victim, whose situation is ultimately a critical commentary on the South African experience of oppression.

\section{In prison}

the clouds assume importance

and the birds

With a small space of sky

cut off by walls

of bleak hostility 
and pressed upon by hostile authority

the mind turns upward

when it can -

Clichés about the freedom of birds

and their absolute freedom from care

become meaningful

\section{(1973, pp. 65-66, my emphases)}

The word "image" is used here in the general sense of the overall picture or tonality of a poem or of the poetry as a whole resulting from stylistic devices, as well as in the sense of an image as a "description of visible objects and scenes" (Abrams, 2012, p. 169). Brutus's “This sun on this rubble after rain” (1973, p. 9), for example, offers useful insights from the point of view of images in terms of the second conception.

This sun on this rubble after rain.

Bruised though we must be

some easement we require

unarguably though we argue against desire.

Under jackboots our bones and spirits crunch

forced into sweat-tear-sudden slush

- now glow-lipped by this sudden touch:

- sun-stripped perhaps, our bones may later sing

or spell out some malignant nemesis

Sharpevilled to spearpoints for revenging

but now our pride-dumbed mouths are wide

in wordless supplication

- are grateful for the least relief from pain

- like this sun on this debris after rain.

In this poem, the image of conflict may be located in the description of the general scene of devastation which stands on the other side from the pleasant sunshine on the ruin, as well as in the individual objects which suggest the agents and the victims of the devastation, e.g. the jackboots and the debris and rubble. Although those objects or images (of agents and victims of oppression) are in mutual opposition, they are bound by the same context of devastation to which they all refer, thereby constituting two opposing parts of a composite picture.

Finally, the concept is also used in the more general sense in which an image may also realise itself as metaphor or simile, in other words, all the objects and qualities of sense perception in a poem (Abrams, 2012, pp. 169-70).

From this perspective also, "The sun on this rubble after rain" offers additional insights. In that poem, the image does not only consist in 'visual perception,' for we not only 'see' the images (of devastation, of rubble and debris) in 'our mind's eyes' but also 'hear' them in 'our mind's ears' as well as realise their sensations in several other ways. For instance, we 'feel' the warmth of the sun after the cold "rain"; we 'hear' the 'crunching' sound of bones and spirits in their opposition to and encounter with the brutal and vicious jackboots. We also 'hear' the 'slushing' sounds of the gruesome concoction involving sweat and tear with crunched spirits and bones. The auditory appeal is itself enhanced by sound effects, especially the preponderance of sibilant sounds in the two lines where the image occurs:

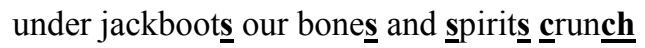




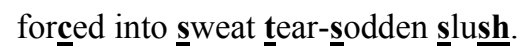

The 'slushing' sound is emphasised by auditory effects. That, however, merely introduces us to another level of opposition in the co-occurring images, especially a phonic opposition, between the cacophonous, plosive and harsh sounds in "jackboots," "unarguably," "bruised" (relating to the oppressors), and the generally soft and sibilant sounds in such words as "slush," "spirits," and "forced" (referring largely to the victimised opponents of the jackboots). In other words, again, two opposing parts of a single image whose 'relationship,' paradoxically, is in the mutual opposition of the parts.

\section{A Structure of Simultaneous Opposites}

As earlier stated, one notices how, through Brutus's binary structures, several levels of opposition may be simultaneously present sometimes in any one of his poems. In the foregoing poem, for instance, it may be seen in the juxtaposition of the following images: sunshine with rainfall, oppressive jackboots with oppressed crunched bones and spirits, a present pain with a future hope, and so on. There is the further antithesis of wordlessness and supplication, bruising and 'easement,' arguing 'unarguably,' victim and aggressor, vengeance - against the un-Named but clearly defined Aggressor, etc.

One has variously shown by the foregoing, that the image, according to Richards, as quoted in Wellek \& Warren (1976, p. 187), may be conceived of both in terms of its "vividness as an image" and also as "a mental event peculiarly connected with sensations"; sensations as much of thought as of taste, touch, sight, sound, smell. An image, therefore, has reference beyond 'qualities of sense perception,' although it frequently is. By means of it the poet gives form (acoustic, gustatory, visual, haptic, thermal, psychological, etc.) to something which is otherwise 'inapprehensible,' like the mental agony 'concretised' through the rubble and debris in "This sun on this rubble after rain.”

\section{Binaries of the Concrete and the Abstract}

Another example of the relationship of conflicts in Brutus's images may be seen in the concretisation of abstract realities; in other words, a paired relationship of dissimilitude between an abstract (usually mental) state and a 'concrete' object or scene. Through such means, the inapprehensible abstract state receives 'concrete' form.

In "This sun on this rubble after rain," again, the image of crunched "spirits" under jackboots suggests that the description of the ravaged scene is actually a presentation of something inner, something less apprehensible. By means of the concrete images of rubble and debris, the poet achieves a transformation of the abstract experience of suffering and oppression into a 'concrete' and more apprehensible form. A balance between the abstract and the concrete, between the internal and the external, results in the relationship between the opposite states.

In that poem, the rubble and the debris also serve both a similaic and a metaphoric function; a similaic function when the anticipated 'glow-lipping' sunshine of hope is presented in terms of or 'concretized' "Like this sun on this rubble after rain," and a metaphoric function as we are invited to see the ravaged people, or their inapprehensible pains, in terms of those material ravages whose referents are the sufferers themselves.

Adrian Roscoe (1977) has properly observed that in that poem, Brutus

identified himself and his community with this rubbish. He and his people are the cast-offs of South African society, the garbage spilling from an opulent lifestyle (p. 161).

The common ground in the poem between the images of rubble and debris on the one hand (which it seems to me contextually inappropriate for Adrian Roscoe to speak of as "rubbish" and "garbage"), and the people they refer to, on the other, is the likeness they all share as occasioned wrecks, as eloquent vestigial victims of a wreaked havoc, an "inflicted loathsomeness" (Brutus, 1978, "Sherds," p. 30).

One readily agrees with T. Coll MacGregor (1995) that "images come more or less naturally to Brutus," but it is hard to accept his further position that "the poet regards himself as a passive observer of myriad images"; that "he ultimately rejects ideas, abstractions, as having no basis in reality" (p. 68, my emphasis). One observes, on the contrary, that, rather than reject abstractions and ideas, Brutus usually transmutes them into more apprehensible 'concrete' images; not a rejection of one level of experience, but the expression of it by an opposite kind of experience; a technique which, to my mind, is sociologically significant, because it ultimately points to the contradictions in the poet's society, of two opposite forces related at the same time as they are divided by the fact of 
their social context and the issues of race and politics. According to Tanure Ojaide (2007) the Nigerian poet, every writer makes a choice on what side to stand in the perennial battles of social oppositions (p. 3). Brutus does not make a choice for no man's land. He stands with the victims of the evils he portrays.

Not in all poems is Brutus's structural generation of opposition very apparent, and not in all poems does it clearly suggest conflict, although the phenomenon ultimately points to that condition in the poet's society. We find in the poem, "At Night," for example, the juxtaposition of a concrete experience with an abstract notion. The 'concrete' setting of the prison cell provides the background to the opposite abstract emotion (and thoughts) about freedom.

$$
\begin{aligned}
& \text { At night } \\
& \text { on the smooth grey concrete of my cell } \\
& \text { I heard the enormous roar of the surf } \\
& \text { and saw in my mind's eye } \\
& \text { the great white wall of spray rising } \\
& \text { like a sheet of shattering glass } \\
& \text { where the surge broke } \\
& \text { on the shore and rock and barbed wire } \\
& \text { and going to the shed } \\
& \text { in hope of a visitor } \\
& \text { I greeted the great cypress } \\
& \text { green and black } \\
& \text { dreaming in their poised serenity } \\
& \text { in the limpid stillness of the brilliant } \\
& \text { afternoon } \\
& \text { gracious as an Umbrian Raphael landscape } \\
& \text { but more brilliant and more sharp. }
\end{aligned}
$$

(Brutus, 1978, p. 83)

\section{The Paradox of Confinement and Mobility}

Beyond the opposition between a concrete and an emotional state, which the image serves in that poem, it is also possible to establish a relationship of paired oppositions between images on a kinaesthetic level; for instance between the poetic persona's relative stasis in the imprisoning walls of the cell, and the motion of the great white surging "wall" of surf breaking on the shore "Like a sheet of shattering glass." The freedom and energy of the surf on the one hand stand in opposition to the limitations of the apparently helpless prisoner on the other. Ultimately, it is not only a counterposition between motion and "stillness" but also between freedom and confinement.

In spite of the opposite nature of their experiences, both restricted prisoner and free, surging, locomobile waves may be identified together in the fact that even the free and boundless waves also terminate, in a way coincidental with the poet-persona's incarcerated circumstances, at "The shore and rock and barbed wire" which define the borders of the prison. In other words, the same boundaries that define the extremes of the prisoner's movement also limit or restrain the boundless energy of the waves. In a similaic sense, then, we are impelled to view the confinement and indeed the personality of the captured and imprisoned freedom fighter and poet-persona in terms of the "enormous" roaring and surging "great white" surf that also terminates at the same "barbed wire" and rocky restraints. In some sense, then, the arrested great waves become a picture of the incarcerated 'enormous' freedom fighter. Furthermore, the dissimilar pair of prisoner and roaring waves, technically, also stresses the predicament as well as accentuates the emotional agony of the imprisoned persona in dire expectation of a visitor. Sadly, the prisoner cannot be reached (or 'visited') even by the free, surging waves which, unfortunately, disintegrate irrevocably and irredeemably, "Like a sheet of shattering glass" at those same "barbed wire" and rocky prison boundaries of his confinement. In this way, Brutus works the abstract emotion of loneliness against the physical images of the surf. The prisoner, the waves, the cell, the barbed wire, etc., all become different but unified strands in a delicate imagistic interweaving of bifilar 
emotional and physical phenomena. This is Brutus's peculiar structure of paired units of meanings; units which often have a relationship of opposition and, at times, of complementality.

Brutus's interfusion of disparate objects (as here between the confined prisoner and the boundless waves, and ultimately between confinement and freedom), between disparate moods (as between the loneliness of the prisoner and the exuberance of the roaring and surging waves), etc., sometimes results in a cumulation of images which speak simultaneously at several levels, but which, however, can still be reduced to antithetical units by means of which the poet dramatizes the usually volatile South African concurrence of antagonistic forces.

John Lent (1995), in his essay, “'Turning stones to Trees': The Transformation of Political Experience in Dennis Brutus' Strains," finds a similar sociological relevance in this technique of Brutus. He states:

By manipulating us into psychological realities through such vivid images of landscape in this way, I believe Brutus succeeds in forcing the love and horror in his homeland out into the relief of our own consciousness, and this, more than simplicity or rhetoric, is the real political achievement in this volume of poetry (p. 110)

In other words, Brutus's peculiar antithetics or juxtaposition of opposites (here, of psychological and physical realities) is to be appreciated against the background of his peculiar social experiences. Furthermore, the juxtaposition lends force to (and itself ultimately assumes the strong voice of) a political statement from the pen of a man who, even though dead, is still acclaimed one of South Africa's foremost contemporary poets.

\section{Conclusion: The Present Appeal of Past Rhythms}

While no one will contest the claim that a "wind of change" once upon a time blew through South Africa and "brought sudden transformations" that also took away the steam from political 'writers' whose prominence was less in their aesthetics than in their denunciation of social inequalities (Ibinga, 2014), to the extent that the official end to apartheid has not eradicated the universal and local spots of struggle against oppression, writers like Dennis Brutus will still have the microphone. The point is probably succinctly captured in Charles Crawford's rather enigmatic headline, "Mandela Dies, Apartheid Lives" (2013). In other words, even with the official end to apartheid, the shift in social concerns and consequently in creative focus has not meant a change in function for South African literature.

Dennis Brutus's rhythms have remained fresh now as then under the shadows of apartheid. The enduring appeal of his poetry is a testimony to its beauty over and above the duties that had midwifed it; it is the lasting relevance of good painting - the classic painting of a social landscape on the canvas of art.

\section{References}

Abrams, M.H (2012). A glossary of literary terms. (10th ed.). Australia: Wadsworth.

Bond, P. (2009, December). Dennis Vincent Brutus, 1924-2009. Monthly Review. Retrieved from http://mrzine.monthlyreview.org /2009/brutus261209.html

Brutus, D. (1973). A simple lust. London: Heinemann.

Brutus, D. (1978). Stubborn hope. London: Heinemann.

Crawford, C. (2013, December 15). Mandela dies, apartheid lives. Retrieved from http://www.thecommentator.com/article/4459/mandela.dies_apartheid_lives

Ibinga, S.S. (2014, December). Post-apartheid literature beyond race. This Century's Review. Retrieved from http://history.thiscenturysreview.com/post_apartheid.html

Lent, J. (1995). 'Turning stones to trees': the transformation of political experience in Dennis Brutus' Strains. In C.W. McLuckie \& P.J. Colbert (Eds.), Critical perspectives on Dennis Brutus (pp. 99-112). Colorado Springs: Three Continents Press,

MacGregor, T. C. (1995). 'Africanness' and Poems from Algiers. In C.W. McLuckie \& P.J. Colbert (Eds.), Critical perspectives on Dennis Brutus (pp. 60-69). Colorado Springs: Three Continents Press.

Mzamane, M.V. (April 1985). Sharpeville and its aftermath: the novels of Richard Rive, Peter Abrahams, Alex La Guma, and Lanretta Mgcobo. ARIEL 16(2), 31-44.

Nkosi, L. (1981). Tasks and masks: themes and styles of African literature. Harlow, Essex: Longman. 
Ojaide, T. (2007). Ordering the African imagination: essays on culture and literature. Lagos, Nigeria: Malthouse Press.

Pieterse, C. (1978). Dennis Brutus: interview with Cosmo Pieterse. In D. Duerden \& C. Pieterse (Eds.), African writers talking (pp. 53-61). London: Heinemann.

Roscoe, A. (1977). Uhuru's fire: African literature east to south. Cambridge: Cambridge UP.

Sanchez, B. (2003). Brutus, Dennis 1924-; contemporary black biography. Encyclopedia.com. Retrieved 2014, December 16 from http://www.encyclopedia.com

Tutu, D. (2014, December). Poetry and protest. Retrieved from http://www.amazon.com/Poetry-Protest-Dennis-Brutus-eader/dp/1931859221/ref=sr_1_1/182-5977836-590131 4? ie $=$ UTF8\&qid $=1418121243 \&$ sr $=8-1 \&$ keywords $=$ Dennis + Brutus $\& p e b p=1418121258285$

Wauthier, C. (1978). The literature and thought of modern Africa. London: Heinemann.

Wellek, R., \& Warren, A. (1976). Theory of literature. Middlesex: Penguin.

Wisner-Broyles, L. A. (1999). Ed. Poetry criticism 24. Gale Cengage eNotes.com. Retrieved 2014, December 16 from http://www.enotes.com/topics/dennis-brutus\#critical-essays-brutus-dennis-introduction 